\title{
The Impact of External Development on the EConomic and Aesthetic Values of Theodore Roosevelt National Park
}

\author{
George Wallace $\uparrow$ Pat ReEd $\uparrow$ John McKean

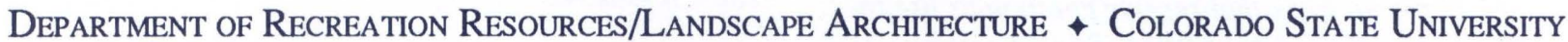 \\ ForT COLLINS
}

Theodore Roosevelt National Park (TRNP), the only national park and wilderness in the United States, to represent a "mixed grass prairie ecosystem, has considerable external development near its boundaries. Park managers have wanted to know to what extent such development was affecting park values and the visitor's experience. They also wanted a better estimate of the park's contribution to the local and state economy so that changes in visitation might be viewed in economic terms. Additional information about visitor perceptions, preferences, and characteristics was also requested.

During the summers of 1988 and 1989, a combination of on-site interviews at six integral park vistas and a mailback questionnaire were used to gather such data. Photo simulations depicting the addition or removal of man-caused features were used as well as the actual landscape appearing in the photo to obtain visitor perceptions regarding external development. Post-visit mailback questionnaires were used to gather data about visitor expenditures, activities and characteristics. Economic data (both visitor expenditures a park operational expenditures) were run through an input-output model to estimate the economic value of the park.

\section{- EXternal DEvelopment and THE VisITOR EXPERIENCE}

Theodore Roosevelt National Park is a visually-oriented park where people spend much time at the various scenic vistas looking at the open landscape, viewing wildlife, and taking pictures. The terrain has many long and sweeping viewsheds that go beyond park boundaries and on which unnatural landscape features are noticeable. At all six vistas where sampling was done, the simulated removal of visual impacts (human-made or human caused features associated with external development, i.e. powerlines, oil and gas wells etc.) increased visitor ratings of landscape attractiveness while the simulated inclusion of such landscape features lowered attractiveness ratings. In most cases even subtle simulated changes in landscape features caused noticeable differences in landscape attractiveness ratings. Moreover, increases in external development occurring at these sites between 1988 and 1989 show up distinctly in the data.

Although visitors still rate their experience at TRNP as good,external development (particularly oil and gas development and its associated structures, roads, dust, odors and noise), is negatively affecting their experience. Visitors report that they experience such things and that they detract from their visit, and 
that they will spend less time doing a variety of activities in sections of the park where such development is present nearby. Some visitors, especially those who seek a more pristine backcountry setting, have indicated they may stop coming to the park because of external development.

Not all landscape features caused by humans detract from the visitor's experience. The study reveals that park visitors view objects on the landscape in a given context and assign meanings to them. By way of example, visitors tell us that smoke from natural sources (burning coal seams etc.) does not detract from the visitor experience while smoke from oil and gas wells detracts significantly - even though they cannot normally distinguish between them.

Even though Theodore Roosevelt National Park is off the beaten path, has a prairie/badlands setting not typical of most National Parks, and is not a primary destination park, those that have been there value it highly, often more than other national parks. There is a sizable constituency of repeat visitors whose use of the park changes from more passive to more active, and whose positive evaluation of the park increases the more times they visit. Many of these people are from North Dakota.

Nationwide, there is a growing awareness about the importance of protecting natural and wildland areas within that represent all of our ecosystem types. This seems to be supported in this study by visitor attitudes recognizing the unique nature of the park in this regard. The park's wildlife are particularly valued by visitors. The historical themes protected by the park are highly valued and reinforced by the town of Medora and its emphasis on the historical figure of President Theodore Roosevelt and the area's early history. It is suspected, though visitors were not asked directly, that one of the unique values held by the park and adjacent lands, is the ability to view the landscape as the early settlers might have seen it, as Roosevelt himself saw it and benefitted from its wildness, and to feel the contrast with the increasing development on surrounding pastoral and agricultural lands. These are difficult concepts to quantify in a study but are suggested by comments received on the mailback questionnaires.

\section{Protecting Park Values}

There is strong support among visitors for adhering to the legislation that protects the park's air and water quality even if it means adding to the costs of energy development. There is also strong support for the concept of buffering the park even though the language used ("in which no oil and gas development, transmission lines etc., would be permitted") is stronger than thepolitical realities or existing leases may allow at present.

Local visitors, who value the park highly and make the most return visits, may sometimes have difficulty in reconciling their affinity for the park with their undeniable economic ties to the region's energy industry. They are at once supportive of the park but somewhat less supportive than the majority of visitors for the concepts of buffering and strict adherence to legislation protecting the park. It should be noted, however, that the majority of visitors in each visitor origin category, including locals and others from North Dakota, favor both adherence to the legislation and buffering. At the very least, visitors are certain to support the management of visual resources and the mitigation of the man-made or caused landscape features that are the most intrusive. Data about what visitors see from each of the vistas used as interview sites is directly applicable by NPS staff.

\section{The Park's Economic Contribution}

The Park makes a significant contribution to both the local and State economies, and this study has been able to estimate the number of jobs and millions of dollars that it generates each year - more than 100 million dollars and the equivalent of more than 2,000 extra jobs in the past two years combined. The question partially remains, does external development erode that economic contribution? The data indicates that it does but it is difficult to put dollar value on lost revenues.

Visitors have indicated that external development will reduce the amount of time that they will spend pursuing certain activities near sites that have experienced development. Since the study found that viewing, picture taking, and other activities at these sites are such a prominent part of the experience at TRNP, this reduction in activity must be taken seriously - in economic terms as well as for the other types of value held by the park. Some visitors will stop using the most impacted sites and the cumulative impact produced by external development now present at most vistas could likely cause a smaller percentage 
of visitors to stop using the park altogether.

Calculating the dollar value of these reductions in use is made difficult by several factors. When visitors reduce their length of stay or are displaced, several things might happen. Out of state visitors (the majority) might, indeed, spend that time and money outside the region, but, local people may just spend it elsewhere in North Dakota.

It may also be assumed that since external development has been present for a number of years, that an undetermined number of people, especially repeat users who are the most sensitive to such impacts, have already been displaced or no longer visit the park. Who they are and how much they might have spent is difficult to know.

\section{$\downarrow$ The Relationship With Medora}

The study makes it more apparent that the Park and the town of Medora co-exist in a symbiotic relationship. For many visitors, each enhances the other. The percentages of people with "Medora as primary destination but who decided to visit the park" and vice versa are about equal. Visitors with Medora as their primary destination value the park highly. Medora, if it works together with the TRNP staff, can maintain an atmosphere that will reinforce park values. Results from the study done of visitors to Medora for the Theodore Roosevelt/Medora foundation (1989) reinforce the idea of promoting careful development that does not become too commercialized or lose the western/historical/natural history emphasis. If development in Medora takes another course, (as it could with the airport issue), Park values easily can be threatened.

\section{Visitation Data/Visitor Characteristics}

Given the park's multiple entry points, adjustments can be made in the data describing the number of visitors that the park receives each year. The study has determined, after calculating the multiple entries for our sample, that "real visits" (one party visiting the Park but being counted at several places) are approximately $38 \%$ of the total recorded visitor entries.

TRNP is not a primary destination park but was included in multiple destination trips for $58 \%$ of the visitors surveyed. The Park has a core of dedicated repeat users for whom it often is a primary destination. Many of these visitors are local. Fifty-eight percent of the visitors interviewed were from outside the region and $41.4 \%$ of local and regional origin. The average party size was 2.9 and the mean length of stay 1.9 days. More than $78 \%$ of all visitors came in a family group. First time visitors to the park comprised $57 \%$ of the sample. Forty percent of these newcomers learned about the park from highway maps and signs which draw in a significant number of passers by ( $16.4 \%$ of all visitors are passers by). Park Service information, except for road signs, was not the source of information about the park for most people. The south Unit and the Visitor Center/Museum are visited by about $3 / 4$ of all visitors, while the North Unit receives visits from about half of all visitors.

\section{$\downarrow \quad$ Future Research}

There is a special challenge in protecting the wilderness portion of the Park. The works of man, contrary to the intent of the Wilderness Act, are especially noticeable from many points within the TRNP Wilderness. Backcountry use - especially overnight use, is currently low at the park and the study was not able to focus on wilderness users or the solitude issue mentioned in the original study objectives. Nonetheless, since there is so little prairiewilderness like that found at TRNP, there is a need to do some research specifically on the perceptions of wilderness users about external impacts. Points out, providing and protecting aesthetic resources such as remoteness, solitude, quiet, natural smells, and the opportunity to experience the natural and historical scene of Roosevelt's time (which influenced his life so profoundly), is difficult to do. These park values are often intangible and not sought or perceived by all visitors. This makes them no less important, perhaps more important.

This study has begun to probe the perceptions of the majority of visitors to the park who were encountered at accessible pullovers. To get at the more profound impacts of external development on what might be called the real essence or uniqueness that the park engenders may require a sample of backcountry and wilderness users. This subset of visitors who make the effort to experience these special attributes held by the park may be able to tell us a lot about the incidence of many of the impacts that this study simply has not had the time to cover, including light pollution at night, aircraft and pump noise, hydrogen sulfide odors and others. 